Vol.6 No.1 March 2020

Hal 94-105 DOI: 10.22437/bio.v3i1.4582

Biology Student's Perception of the Implementation of Microteaching

\title{
Persepsi Mahasiswa Biologi Terhadap Pelaksanaan Pembelajaran Mikro
}

\author{
Ali Sadikin ${ }^{1}$, Upik Yelianti ${ }^{2 *}$ \\ ${ }^{1,2}$ Prodi Pendidikan Biologi FKIP Universitas Jambi \\ Kampus Pinang Masak Mendalo Indah, Muaro Jambi-Indonesia \\ *Corresponding Author: upikyelianti@ymail.com
}

Received : 31 January 2019

Revised : 19 February 2020
Accepted : 27 March 2020

Published : 02 April 2020

Abstract: Microteaching is a teaching exercise for prospective teachers with student conditions, material and time that have been arranged in such a way as to provide comfort for prospective teachers to practice teaching. The implementation of microteaching in the Biology Education Study Program FKIP Jambi University has been going on for a long time. Along with the times whether the microteaching is still relevant or the need for innovation, a survey is needed. Therefore this research was conducted with the aim to reveal the biology students' views on the implementation of microteaching. The method uses a descriptive approach with an instrument in the form of a questionnaire. The number of respondents was 270 students. The results of the study report that the implementation of microteaching is going well but needs to be improved in terms of facilities and infrastructure, additional time to practice and curriculum adjustments needed in schools.

Keywords: Perseption, microteaching, biology students.

Abstrak. Pembelajaran mikro (Microteaching) merupakan latihan mengajar bagi calon guru dengan kondisi siswa, materi dan waktu yang telah diatur sedemikian rupa guna memberikan rasa nyaman bagi calon guru untuk latihan mengajar. Pelaksanaan microteaching di prodi pendidikan biologi FKIP Universitas Jambi sudah lama berlangsung. Seiring dengan perkembangan zaman apakah microteaching tersebut masih relevan atau perlu adanya inovasi perlu diadakan survei. Maka dari itu dilakukan penelitian ini dengan tujuan untuk mengungkap pandangan mahasiswa biologi terhadap pelaksanaan microteaching. Metode menggunakan pendekatan deskriptif dengan instrumen berupa angket. Jumlah responden 270 orang mahasiswa. Hasil penelitian melaporkan pelaksanaan pembelajaran mikro berlangsung baik tetapi perlu diperbaiki dari segi sarana dan prasarana, tambahan waktu untuk berlatih dan penyesuaian kurikulum yang dibutuhkan di sekolah.

Kata kunci: Persepsi, Pembelajaran Mikro, mahasiswa biologi.

\section{PENDAHULUAN}

Menjamin ketersediaan lulusan yang berkualitas dan calon guru yang mampu mengajar dengan efektif sesuai kebutuhan peserta didik dan tantangan zaman adalah tantangan tersendiri dalam lembaga pendidikan. Mengindentifikasi strategi pembelajaran yang paling tepat bagi lembaga pendidikan untuk mencetak calon guru yang berkualitas 
adalah pembahasan yang menarik (Barbara et al., 2004; Cochran-smith \& Villegas, 2015). Dalam beberapa dekade telah terjadi perubahan terhadap implikasi dan penelitian tentang pencarian strategi pembelajaran yang tepat dalam mempersiapkan calon guru yang profesional. Perubahan tersebut menyangkut komponen penting dalam program pendidikan calon guru dalam hal pemberian umpan balik, mentoring dan pembelajaran yang menggunakan teknologi. Sementara itu, lembaga pendidikan guru masih sedikit yang mengarah kepada pendidikan yang demikian (Knight, Llyod, Arbaugh, Gamson, Mcdonald, \& James, 2014).

Merekonstruksi ulang program pelatihan calon guru untuk membekali kemampuan yang dibutuhkan dengan kondisi dilapangan masa depan adalah investasi yang pentih (Cochran-smith \& Villegas, 2015). Masyarkat menghendaki lulusan calon guru yang mampu berpikri kritis, berkolaborasi, menguasai teknologi pendidikan, dan mampu memecahkan masalah (Sadikin, A., Kamid, K., \& Hariyadi, B, 2013; Sadikin, A., \& Hakim, N, 2019). Namun disayangkan lembaga pendidikan calon guru masih melakukan kesalahan dengan fokus kepada transfer pengetahuan dan pembelajaran yang masih tradisional (Cochran-smith \& Villegas, 2015). Akan tetapi masih disayangkan penelitian yang berfokus pada pembinaan yang efektif masih relatif sedikit (Stahl et al., 2018). Guru yang baik adalah guru yang mampu membuat siswa menjadi paham terhadap materi yang diajarkannya dan memahami kebutuhan siswa (Budiarti, R. S., \& Sadikin, A, 2015). Selain itu guru harus mampu membimbing siswa agar memiliki kecerdasan emosional yang baik sehingga dapat menghadapi tantangan zaman yang kompleks (Sadikin, A, 2015).

Bentuk program pelatihan bagi calon guru untuk meningkatkan keterampilan mengajarnya disebut pembelajaran mikro (microteaching). Microteaching adalah suatu proses pembelajaran dan praktik yang mengintegrasikan teori yang telah dipelajari dengan praktik di kelas dengan waktu pelaksanaan 10-15 menit dan jumlah peserta didik 2 sampai 5 orang meliputi elemen mikro, keterampilan teknis mengajar, elemen umpan balik, tempat praktik yang nyaman, guru model, laboratorium, dan paket materi (Allen, 1967; Amobi, 2005; Benedetti \& Reed, 1998; Donnelly \& Fitzmaurice, 2011; Ivey \& Authier, 1978; Joyce \& Showers, 1982; Kilic. A, 2010; Özcan \& Gerçek, 2019; Perlberg, 1972; Putrawangsa \& Syawahid, 2018; Rentoul, 1971). Namun apakah pembelajaran mikro ini masih relevan dengan kebutuhan calon guru dan apakah calon guru menghendaki adanya perubahan dan perbaikan sistem pelatihan bagi mereka hal itu perlu dikaji dan di survei 
untuk mendapatkan data yang akurat. Sehingga data tersebut dapat dijadikan dasar untuk mendesain ulang program pembelajaran mikro atau microteacahing.

Pembelajaran mikro di Prodi Pendidikan Biologi FKIP Universitas Jambi sudah lama dilaksanakan. Dari dalam bentuk program pelatihan yang diselenggarakan unit PPL maupun sampai sekarang dalam bentuk pembelajaran mata kuliah. Tetapi belum ada penelitian yang menggali persepsi mahasiswa biologi terutama dalam hal pandangan mereka terhadap pelaksanaan pembelajaran mikro. Penting bagi penulis untuk menyelediki tentang persepsi ini mengingat persiapan calon guru yang bermutu harus memiliki pembelajaran mikro yang berkualitas.

\section{METODE PENELITIAN}

Kami menggunakan jenis penelitian deskriptif kuantitatif. Dengan jumlah sampel 270 orang mahasiswa biologi, yang terdiri dari 84,4 \% perempuan dan 15,6 \% laki-laki. Mereka mulai dari angkatan 2016 dan angkatan 2017. Semua sumpel diberikan angket untuk mengetahui pandangan mereka terhadap pelaksanaan pembelajaran mikro di Prodi Pendidikan Biologi FKIP Universitas Jambi. Hasil angket tersebut akan di analisis dan di jabarkan untuk mendapatkan kesimpulan.

Deskriptif kualitatif merupakan jenis penelitian yang digunakan dalam penelitian ini. Penelitian Deskriptif kualitatif merupakan Penelitian yang menjelaskan uraian atau gambaran terhadap suatu obyek atau kejadian sedalam mungkin yang tidak ada intervensi terhadap kejadian atau obyek yang diteliti (Kountur, 2018; Moleong, 2017; Sukardi, 2015). Hal yang dideskripsikan untuk riset ini ialah pelaksanaan microteaching di Prodi Pendidikan Biologi FKIP Universitas Jambi. Angket yangd digunakan dalam penelitian ini bertujuan untuk mengungkapkan gambaran proses pelaksanaan microteaching di Prodi Pendidikan Biologi FKIP Universitas Jambi. Prosedur Penelitian meliputi membuat instrumen angket, penyebaran angket, reduksi data, analisis data dan penarikan kesimpulan. 


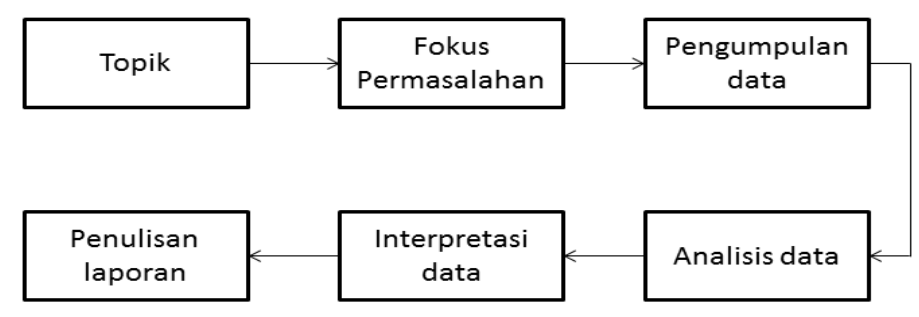

Gambar 1: Prosedur penelitian

Sumber data utama dalam penelitian kualitatif ialah skor angket dan jawaban responden berupa alasan pemilihan jawaban. Sumber data adalah mahasiswa calon guru biologi yang dianggap telah mengikuti program microteaching di Prodi Pendidikan Biologi FKIP Universitas Jambi. Subyek penelitian adalah mahasiswa calon guru biologi yang dianggap telah melakukan program microteaching. Subyek penelitian adalah responden yang dimintai keterangan tetapi tidak diberi perlakuan atau dibiarkan alami (Sugiyono, 2015).

Menurut Arikunto (2013), Instrumen atau Alat Penelitian ialah sarana yang digunakan oleh penelitian untuk menjaring data. Moleong (2017) menambahkan bahwa peneliti berkedudukan dalam penelitian deskriptif kualitatif disini cukup rumit ialah langsung menjadi alat penjaring data itu sendiri dalam penelitian. Instrumen utama dalam studi ini adalah angket atau kuesioner. Maka dari itu peneliti berperan langsung dalam merencanakan, melaksanakan pengumpulan data, menganalisis, menafsirkan data, dan akhirnya melaporkan hasil dan pembahasan serta kesimpulan untuk diinterpretasikan. Data angket dalam penelitian ini dianalisis menggunakan teknis analisis yang mengacu pada pendapat Miles dan Huberman (Sugiyono, 2015) yang meliputi mengumpulkan data dan menyeleksi data (reduksi data), memaparkan data dan (3) penarikan kesimpulan. 


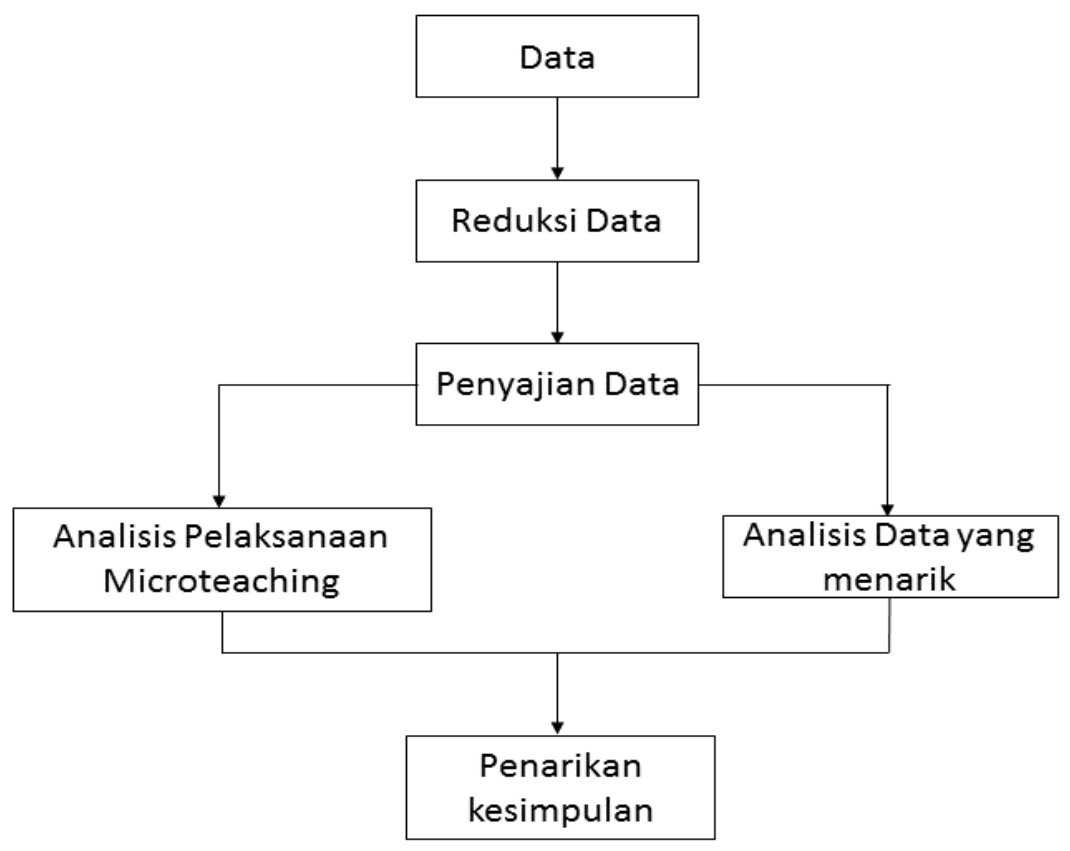

Gambar 2: Proses analisis data

\section{HASIL DAN PEMBAHASAN}

Hasil penelitian melaporkan bahwa jumlah responden yang mengisi angket berjumlah 270 orang mahasiswa biologi. yang terdiri dari 84,4\% perempuan dan $15,6 \%$ laki-laki. Mereka mulai dari angkatan 2016 dan angkatan 2017. Dari survei didapatkan data $86,5 \%$ responden manyatakan microteaching memberikan sangat membantu dalam persiapan calon guru biologi dan 13,5\% menyatakan membantu dalam persiapan calon guru biologi.

Tabel 1: persepsi mahasiswa biologi terhadap persiapan calon guru

\begin{tabular}{|c|c|}
\hline Jawaban responden & Alasan \\
\hline $\begin{array}{l}86,5 \% \text { sangat membantu dalam } \\
\text { persiapan calon guru }\end{array}$ & $\begin{array}{ll}\text { - } & \text { Microteaching mengajarkan calon guru dalam mengajar } \\
\text { - } & \text { Dapat memahami proses belajar mengajar } \\
\text { - } & \text { Dapat mengelola kelas dengan baik } \\
\text { - } & \text { Dapat meningkatkan rasa percaya diri } \\
\text { - } & \text { Dapat memberikan pembekalan sebelum praktik di sekolah } \\
\text { - } & \text { Dapat belajar mengajar yang baik dan benar } \\
\text { - } & \text { Menjadi pengalaman awal bagi calon guru } \\
\text { - } & \text { Melatih calon guru dalam menghadapi siswa dikelas } \\
\text { - } & \text { Membantu mempersiapkan diri menjadi guru } \\
\text { - } & \text { Melatih keterampilan mengajar }\end{array}$ \\
\hline $\begin{array}{l}13,5 \% \text { membantu dalam persiapan } \\
\text { calon guru }\end{array}$ & $\begin{array}{l}\text { - Memberikan bekal dan persiapan ketika mengajar di dalam } \\
\text { kelas }\end{array}$ \\
\hline
\end{tabular}


- Mendapatkan pengalaman baru

- Mendapatkan kesempatan praktek mengajar

- Mendapatkan pengarahan dan bimbingan dari pelatih

- Melatih calon guru untuk mampu berbicara didepan siswa

- Melatih keterampilan mengajar calon guru

- Memudahkan mahasiswa untuk melakukan simulasi

Berdasarkan survei $69,7 \%$ responden menyatakan microteaching dapat sangat membantu meningkatkan rasa percaya diri bagi calon guru. 29,7 \% responden menyatakan microteaching dapat membantu meningkatkan rasa percaya diri bagi calon guru. 0,6 responden menjawab kurang membantu dengan alasan dalam praktek microteaching mengajar di depan teman dikelas bukan murid yang sebenarnya. 60\% responden menyatakan bahwa umpan balik atau saran dari teman sejawat dan pelatih atau dosen memberikan sangat bermanfaat bagi calon guru biologi. $40 \%$ responden menyatakan bahwa umpan balik bermanfaat bagi calon guru biologi. Horgan, K., Howard, S., \& Gardiner-Hyland, F. (2018) melaporkan bahwa pembelajaran mikro mampu meningkatkan rasa percaya diri calon guru dalam mengajar dan juga dapat mengurangi stress calon guru (pre-sevice teacher).

Tabel 2: persepsi mahasiswa biologi dalam meningkatkan rasa percaya diri

\begin{tabular}{|c|c|}
\hline Jawaban responden & Alasan \\
\hline $\begin{array}{l}69,7 \% \text { sangat membantu } \\
\text { meningkatkan rasa percaya diri calon } \\
\text { guru biologi }\end{array}$ & 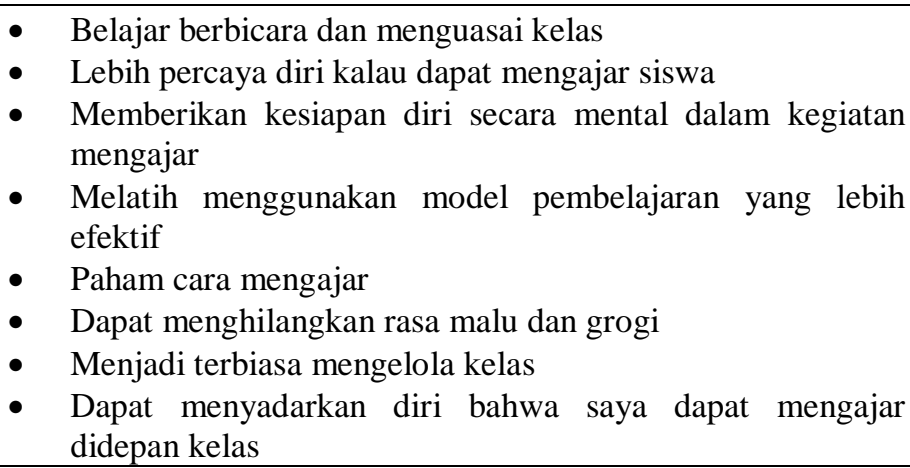 \\
\hline $\begin{array}{l}29,7 \% \text { membantu meningkatkan rasa } \\
\text { percaya diri calon guru biologi }\end{array}$ & $\begin{array}{l}\text { - } \text { Mendapatkan bekal pengetahuan dasar } \\
\text { - } \quad \text { Memberikan latihan untuk berbicara di depan siswa } \\
\text { - } \quad \text { Sudah tahu apa yang akan dilakukan dikelas } \\
\text { - } \quad \text { Karena sudah mendapatkan berbagai ilmu sehingga } \\
\text { menjadi percaya diri } \\
\text { - } \quad \text { Dibekali pengelolaan kelas } \\
\text { - } \quad \text { Dilatih menjadi figur guru }\end{array}$ \\
\hline $\begin{array}{l}0,6 \% \text { kurang membantu } \\
\text { meningkatkan rasa percaya diri calon } \\
\text { guru biologi }\end{array}$ & $\begin{array}{l}\text { - Praktek microteaching mengajar di depan teman dikelas } \\
\text { bukan murid yang sebenarnya }\end{array}$ \\
\hline
\end{tabular}


$.60 \%$ responden menyatakan bahwa umpan balik atau saran dari teman sejawat dan pelatih atau dosen memberikan sangat bermanfaat bagi calon guru biologi. $40 \%$ responden menyatakan bahwa umpan balik bermanfaat bagi calon guru biologi. Umpan balik merupakan energi positif terhadap peningkatan kualitas keterampilan mengajar calon guru (Sadikin, A \& Siburian, J, 2019).

Tabel 3: persepsi mahasiswa biologi terhadap umpan balik dalam pembelajaran mikro

\begin{tabular}{|c|c|}
\hline Jawaban responden & Alasan \\
\hline $\begin{array}{l}60 \% \text { umpan balik atau saran sangat } \\
\text { bermanfaat bagi calon guru biologi }\end{array}$ & $\begin{array}{l}\text { - } \text { Memberikan saran sebelum terjun ke lapangan } \\
\text { - } \quad \text { Memberikan perbaikan proses mengajar supaya menjadi } \\
\text { lebih baik } \\
\text { - } \text { Memberikan gambaran kelemahan calon guru } \\
\text { - } \text { Untuk perbaikan ke depan } \\
\text { - } \text { Dapat membuat evaluasi diri sehingga dapat belajar dari } \\
\text { kesalahan } \\
\text { - Supaya dapat berinovasi dalam pembelajaran } \\
\text { - Supaya tidak terulang lagi kesalahan pada latihan } \\
\text { - } \quad \text { Merikutnya } \\
\text { - Supaya lebih baik lagi } \\
\text { - } \quad \text { Menjadi tahu kesalahan dan kekurangan di saat mengajar }\end{array}$ \\
\hline $\begin{array}{l}40 \% \text { umpan balik atau saran sangat } \\
\text { bermanfaat bagi calon guru biologi }\end{array}$ & $\begin{array}{ll}\text { - } & \text { Untuk memperbaiki kesalahan } \\
\text { - } & \text { Dapat memperbanyak ilmu } \\
\text { - } & \text { Meningkatkan kualitas dalam pembelajaran } \\
\text { - } & \text { Mengetahui letak kesalahan dalam mengajar } \\
\text { - } & \text { Menjadi koreksi bagi calon guru untuk lebih baik lagi } \\
\text { - } & \text { Menjadi lebih berkualitas dalam pembelajaran } \\
\end{array}$ \\
\hline
\end{tabular}

68,6 \% responden menyatakan microteaching sangat membantu meningkatkan keterampilan mengajar bagi calon guru biologi. 30,8\% responden menyatakan microteaching membantu meningkatkan keterampilan mengajar bagi calon guru biologi. 0,6 \% responden menyatakan kurang membantu karena responden merasa tidak ada praktik. 57,3\% responden menjawab microteaching sangat membantu dalam meningkatkan kompetensi profesional calon guru biologi. $40 \%$ responden menjawab microteaching dapat membantu meningkatkan kompetensi profesional calon guru biologi. 2,7 \% menjawab kurang membantu karena menurut responden latihan mengajar hanya dilakukan satu kali praktek, peserta didik diperankan oleh teman bukan siswa sebenarnya, waktunya sangat sedikit, dan perlunya latihan terus menerus. Pembelajaran mikro dapat meningkatkan keterampilan mengajar calon guru (Ardi, M, 2016). Keterampilan dalam menggunakan media pembelajaran biologi juga bertambah ketika melaksanakan pembelajaran mikro (Apriana, E, 2015). 
Tabel 4: Persepsi mahasiswa biologi terhadap peningkatan keterampilan mengajar

\begin{tabular}{|c|c|}
\hline Jawaban responden & Alasan \\
\hline $\begin{array}{l}68,6 \% \text { sangat membantu } \\
\text { meningkatkan keterampilan mengajar } \\
\text { calon guru biologi }\end{array}$ & $\begin{array}{ll}\text { - } & \text { Memahami metode yang digunakan } \\
\text { - } & \text { Mengetahui model dan cara belajar } \\
\text { - } & \text { Kita dituntut untuk lebih berkreativitas lagi } \\
\text { - } & \text { Memahami media yang bervariasi } \\
\text { - } & \text { Memahami langkah-langkah pembelajaran } \\
\text { - } & \text { Karena dilakukan praktek mengajar di kelas } \\
\text { - } & \text { Memberikan pengalaman yang sama seperti di kelas yang } \\
\text { - } & \text { Kebenarnya } \\
\text { - } & \text { Penampilan teman memberikan ide baru bagi } \\
\text { - } & \text { pengembangan pembelajaran }\end{array}$ \\
\hline $\begin{array}{l}30,8 \% \text { membantu meningkatkan } \\
\text { keterampilan mengajar calon guru } \\
\text { biologi }\end{array}$ & 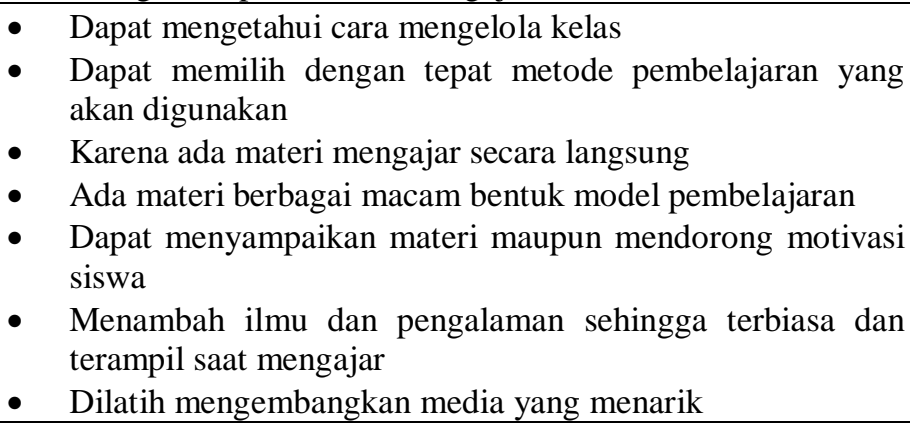 \\
\hline $\begin{array}{l}0,6 \% \text { kurang membantu dalam } \\
\text { meningkatkan keterampilan mengajar } \\
\text { calon guru biologi }\end{array}$ & - $\quad$ Saya merasa tidak ada praktek \\
\hline
\end{tabular}

Kelemahan pelaksanaan microteaching di prodi pendidikan biologi FKIP Universitas Jambi adalah 45,9 \% dikarenakan kurangnya sarana dan prasarana. 44,9 \% kurangnya latihan berulang, $20 \%$ karena kurangnya pemahaman konten atau materi, dan $19 \%$ karena kurang memahami pedagogik. Mengenai pertanyaan apakah mahasiswa biologi memahami tentang pembuatan program tahunan dalam pembelajaran. Mereka menjawab 28,6 \% kurang memahami dan 57,3\% memahami dan hanya 11,9\% sangat memahami serta 2,2 \% tidak memahami. Mahasiswa biologi kurang memahami dikarenakan terlalu singkat penjelasan materi tersebut ketika perkuliahan, belum pernah membuat program tahunan, kurang memahami materi tersebut, karena belum memahami manfaatnya, tidak pernah diulang lagi dalam membuat program tahunan sehingga lupa lagi, dan belum mendapatkan informasi mengenai hal tersebut. Kelemehan persiapan dan pelaksanaan microteaching ini perlu dicarikan solusinya yaitu dengan mengadakan FGD antara guru pamong dan dosen pembimbing PLP/PPL untuk mendapatkan pemahaman yang sama dalam menyingkapi kekurangan ini (Sadikin, A \& Siburian, J, 2019). Sebab implikasi dari pembelajaran mikro ini adalah calon guru mampu mengajar dengan baik 
dalam kelas real teaching (Syafi'i, M, 2014). Penggunaan media pembelajaran yang tepat dalam pelaksanaan pembelajaran mikro juga perlu terus dikemangkan (Apriana, E,2015). Handhika, J. (2016) melaporkan perlunya mata kuliah prasyarat sebelum mengambil mata kulia pembelajaran mikro.

\section{KESIMPULAN}

Hasil penelitian melaporkan persepsi mahasiswa biologi terhadap pelaksanaan pembelajaran mikro di Prodi Pendidikan Biologi FKIP Universitas Jambi bahwa pelaksanaan pembelajaran mikro sangat membantu, membantu dan kurang membantu. Sangat membantu karena microteaching dapat melatih keterampilan mengajar, meningkatkan rasa percaya diri, dan umpan balik memberikan masukkan bagi perbaikan mengajar calon guru. Sebagian kecil mahasiswa biologi mengungkapkan mereka kurang terbantu adanya microteaching karena ada juga dari mereka yang tidak mendapatkan kesempatan praktek langsung dalam mengajar, dan mereka mengajar teman sendiri bukan murid yang sebenarnya.

\section{DAFTAR PUSTAKA}

Allen, D. W. (1967). Micro-teaching: a new framework for in-service education. 1-7.

Allen, D. W. (1979). Microteaching: a personal review. 1-9.

Amobi, F. A. (2005). Preservice Teachers ' Reflectivity on the Sequence and Consequences of Teaching Actions in a Microteaching Experience. Teacher Education Quarterly, 32(1), 115-130.

Apriana, E. (2015). Penggunaan Berbagai Media Pembelajaran Biologi Pada Mata Kuliah Pembelajaran Mikro (Microteaching). Jurnal Biology Education, 4(1). http://dx.doi.org/10.32672/jbe.v4i1.143

Ardi, M. (2016). Pelaksanaan Pembelajaran Micro Teaching Bagi Mahasiswa Program Studi PPKN STKIP-PGRI Pontianak. Edukasi: Jurnal Pendidikan, 12(1), 75-84. http://dx.doi.org/10.31571/edukasi.v12i1.192

Arikunto, S. (2013). Prosedur penelitian atau pendekatan praktik. Cet XV. 
Arsal, Z. (2014). Microteaching and pre-service teachers' sense of self-efficacy in teaching. European Journal of Teacher Education, 37(4), 453-464. https://doi.org/10.1080/02619768.2014.912627

Barbara, Nye, Spyros, Konstantopoulos, Larry, \& Hedges, V. (2004). How Large Are Teacher Effects? Educational Evaluation and Policy Analysis, 26(3), 237-257.

Bell, N. D. (2007). Microteaching: What is it that is going on here? Linguistics and Education, 18(1), 24-40. https://doi.org/10.1016/j.linged.2007.04.002

Benedetti, T. A., \& Reed, M. K. (1998). Supervising Student Teachers Using Peer Coaching. 1-19.

Budiarti, R. S., \& Sadikin, A. (2015). Pengaruh kartu kwartet animalia dengan model TGT terhadap pemahaman materi taksonomi hewan siswa sman 8 kota jambi. BIODIK, l(1).

Cochran-smith, M., \& Villegas, A. M. (2015). Framing Teacher Preparation Research : An Overview of the Field, Part 1. Journal of Teacher Education, 66(1), 7-20. https://doi.org/10.1177/0022487114549072

Donnelly, R., \& Fitzmaurice, M. (2011). Towards productive reflective practice in microteaching. Innovations in Education and Teaching International, 48(3), 335-346. https://doi.org/10.1080/14703297.2011.593709

Handhika, J. (2016). Dampak Pelaksanaan Pengajaran Mikro Berorientasi Pada Penguasaan Materi Terhadap Kualitas Mengajar Mahasiswa PPL. Jurnal Pendidikan Fisika dan Keilmuan (JPFK), 2(2), 78-82. http://doi.org/10.25273/jpfk.v2i2.698

Hargie, O. (1982). Research paradigms and theoretical perspectives in microteaching. British Journal of Educational Technology, 13(1), 76-82.

Horgan, K., Howard, S., \& Gardiner-Hyland, F. (2018). Pre-service teachers and stress during microteaching: An experimental investigation of the effectiveness of relaxation training with biofeedback on psychological and physiological índices of stress. Applied Psychophysiology and Biofeedback, 43(3), 217-225.

Ivey, A. E., \& Authier, J. (1978). Microcounseling: Innovations in interviewing, 
counseling, psychotherapy, and psychoeducation. Charles C Thomas.

Joyce, B., \& Showers, B. (1982). The coaching of teaching. Educational Leadership, 40(1), 4-10.

Kilic. A. (2010). Learner-Centered Micro Teaching in Teacher Education. International Journal of Instruction, 3(1), 77-100.

Knight, S. L., Lloyd, G. M., Arbaugh, F., Gamson, D., Mcdonald, S. P., \& Jr, J. N. (2014). Professional Development and Practices of Teacher Educators. Journal of Teacher Education, 65(4), 268 -270. https://doi.org/10.1177/0022487114542220

Koross, R., \& Kipkenda, P. K. (2016). The short message service (SMS) texting style of communication and its impact on Kenyan University students' written communication skills. International Journal of Scientific Research and Innovative Technology, 3(6), $151-162$.

Kountur, R. (2018). Metode penelitian untuk penulisan skripsi dan tesis. PPM.

Moleong, L. J. (2017). Metodologi penelitian kualitatif (Revisi). Bandung: PT Remaja Rosdakarya.

Özcan, Ö., \& Gerçek, C. (2019). Multidimensional analyzing of the microteaching applications in teacher education via videograph. European Journal of Teacher Education, 42(1), 82-97. https://doi.org/10.1080/02619768.2018.1546285

Pearlman, R. (2018). Recognizing Artificial Intelligence (AI) As Authors and Inventors Under U.S. Intellectual Property Law. Richmond Journal of Law \& Technology, 24(24), 1-38.

Perlberg, A. (1972). Microteaching. International Review of Education, I(1), 547-560. https://doi.org/https://doi.org/10.1007/BF01450315

Putrawangsa, S., \& Syawahid, M. (2018). Model Kegiatan Microteaching Untuk Pembelajaran Matematika Berpusat Pada Siswa. Jurnal Elemen, 4(1), 50-65. https://doi.org/10.29408/jel.v4i1.497

Rentoul, J. (1971). Self Instruction Using Microteaching And Videotape Feedback During 
An In-Service Education Course For Teachers Of Harvard Project Physics. Research in Science Education, 1(1), 79-80.

https://doi.org/https://doi.org/10.1007/BF02558519

Sadikin, A \& Siburian, J (2019). Analisis pelaksanaan Pengenalan Lapangan Persekolahan (PLP) FKIP Universitas Jambi bidang studi pendidikan biologi di SMA PGRI Jambi. Bioeduscience: Jurnal Pendidikan Biologi dan Sains. 3 (2). 10.29405/..bes/3290-993562

Stahl, G., Sharplin, E., \& Kehrwald, B. (2018). Real-Time Coaching and Pre-Service Teacher Education. Springer. https://doi.org/10.1007/978-981-10-6397-8

Sadikin, A. (2015). Hubungan EQ (Emotional Quotient) dengan hasil belajar mahasiswa biologi semester Ganjil Tahun Ajaran 2014/2015. BIODIK, l(1).

Sugiyono, P. (2015). Metode penelitian kombinasi (mixed methods). Bandung: Alfabeta.

Sadikin, A., \& Hakim, N. (2019). Pengembangan Media E-Learning Interaktif Dalam Menyongsong Revolusi Industri 4.0 Pada Materi Ekosistem Untuk Siswa SMA. BIODIK, 5(2), 131-138. https://doi.org/10.22437/bio.v5i2.7590

Syafi'i, M. (2014). Implikasi Pembelajaran Mikro Dalam Pengembangan Keterampilan Mengajar Di Madrasah. Religi: Jurnal Studi Islam, 5(2), 228-250.

Sadikin, A., Kamid, K., \& Hariyadi, B. (2013). Profil Berpikir Kritis Mahasiswa Tipe Phlegmatis dalam Pemecahan Masalah Biologi. Edu-Sains: Jurnal Pendidikan Matematika dan Ilmu Pengetahuan Alam Universitas Jember, 2(2), 59535.

Sukardi, H. M. (2015). Metode penelitian pendidikan tindakan kelas: implementasi dan pengembangannya. Jakarta: Bumi Aksara. Cetakan Ke-3. 